\title{
A preliminary study of marine water quality status using principal component analysis at three selected mangrove estuaries in East Coast Peninsular Malaysia
}

\author{
Saiful Iskandar Khalit a,b, Mohd Saiful Samsudin a, ${ }^{a}$, Azman Azid a,b, Kamaruzzaman Yunus ${ }^{c}$, \\ Muhammad Amar Zaudi ${ }^{d}$, Zati Sharip ${ }^{e}$, Syazrin Syima Sharifuddin ${ }^{f}$, Tariq Mubarak Husin ${ }^{g}$ \\ a Faculty of Bioresources and Food Industry, Universiti Sultan Zainal Abidin, Besut Campus, 22200 Besut, Terengganu, Malaysia \\ b UniSZA Science and Medicine Foundation Centre, Universiti Sultan Zainal Abidin, Gong Badak Campus, 21300 Kuala Nerus, Terengganu, \\ Malaysia \\ Kulliyyah of Science, International Islamic University Malaysia, 25200 Kuantan, Pahang, Malaysia \\ ¿ Department of Environmental Science, Faculty of Environmental Studies, University Putra Malaysia, 43400 UPM Serdang, Selangor, Malaysia \\ e Water Quality and Environment Research Centre, National Hydraulic Research Institute of Malaysia, 43300 Seri Kembangan, Selangor, Malaysia \\ Water Quality Laboratory, National Hydraulic Research Institute of Malaysia, 43300 Seri Kembangan, Selangor, Malaysia \\ $g$ Forestry and Environment Division, Forest Research Institute Malaysia (FRIM), 52109 Selangor, Malaysia \\ * Corresponding author: saifulsamsudin294@gmail.com
}

Article history

Received 22 May 2017

Accepted 4 October 2017

\begin{abstract}
This research presents marine water quality status in three different mangrove estuaries. The objective of this study is to evaluate the surface water quality of three estuaries in east coast Peninsular Malaysia. The parameters measured were Dissolved Oxygen (DO), $\mathrm{pH}$, Biochemical Oxygen Demand (BOD), Salinity (SAL), total dissolved solid (TDS), ammonium $\left(\mathrm{NH}_{4}-\mathrm{N}\right)$, turbidity (TUR), total suspended solid (TSS) and coliform. Monthly sampling was performed during the dry season, from June 2016 until September 2016. Data were analysed using principal component analysis (PCA). PCA yielded two PCs where VF1 forms strong factor loadings for $\mathrm{pH}, \mathrm{NH}_{4}-\mathrm{N}, \mathrm{SAL}$, and TDS signifying saltwater intrusion in mangrove area. VF2 designed strong factors of BOD, TUR and Coliform and strong negative loading of DO indicating anthropogenic pollutions in the area. This study output will be a baseline setting for future studies in mangrove estuary marine water quality. Mangrove marine water samples of future monitoring studies in mangrove estuary will benefit by enabling understanding of pollution loading and coastal water quality. It is essential to plan a workable water quality modelling as powerful tool to simulate marine water quality and forecast future consequences to facilitate mangrove biodiversity conservation.
\end{abstract}

Keywords: Marine water quality, Mangrove, Estuaries, South China Sea, Principal component analysis

(C) 2017 Penerbit UTM Press. All rights reserved

\section{INTRODUCTION}

Mangrove is known as a unique, and endangered, coastal ecosystems that plays a vital role in tropical and subtropical regions, located in the intersection between land and sea (Holguin et al. 2001). This ecosystem acts as a buffer area being essential for maintaining the sea level and for protecting the coast (Duke et al. 2007). Mangrove habitats also function as sinks for ensnaring heavy metals under normal circumstances. The mangroves will become an inception for discharge of pollutants once the habitats are disturbed by natural disaster or human activities. Pollution and destruction of mangrove forest can also affected river water quality. Reported negative impacts of mangrove loss include reducing marine water quality, eradicating fish nursery habitats, decreasing biodiversity and affecting adjacent coastal habitats (Mumby, 2004). In addition, mangrove loss might affect tourism income for the country and demolition of the associated mangrove ecosystem especially flora and fauna (Sandilyan and Kathiresan, 2014). The interaction of ground water and surface water that was affected by human activities and natural process may cause unfavorable aquatic environment and the water can receive pollution load naturally without decreasing in quality (Kumar and Murty, 2011). However overflow of pollutant that reaches any water bodies' maximum capacity is dangerous to living organism. Common changes may occur due to natural phenomena (dissolution, precipitation and sorption) during heavy metal transportation in the riverine system. Mangrove forest shows decreasing biodiversity resulting from ecosystem disturbance (Hauff et al. 2006). Due to the increasing human population, the exploration of mangrove forest through human activities such as logging activities, deforestation, agricultural land, aquaculture activity and industrial waste gives negative environmental impact especially to water quality of mangrove forest (Hauff et al. 2006). Thus, water quality measurement is compulsory for managing safe and reliable water sources. Poor water quality is harmful to living organisms and the ecosystem. Given these environmental issues, several studies have been done on monitoring marine water quality in mangrove areas, exclusively to give comprehensive picture of the forces acting on mangrove ecosystem. Some examples related to this research include the mangrove swamps of Ariyankuppam estuarine complex, Pondicherry, India (Satheeshkumar and Khan, 2012), Port Dickson, Malaysia (Praveena and Aris, 2013), and Upper Merbok Estuary, Kedah, Malaysia (Ismail and Ibrahim, 2015). This work is the first preliminary study to evaluate the surface water quality of three mangrove estuaries in east coast of Peninsular Malaysia (Semerak Lagoon, Setiu Wetland and Merang Estuary). 


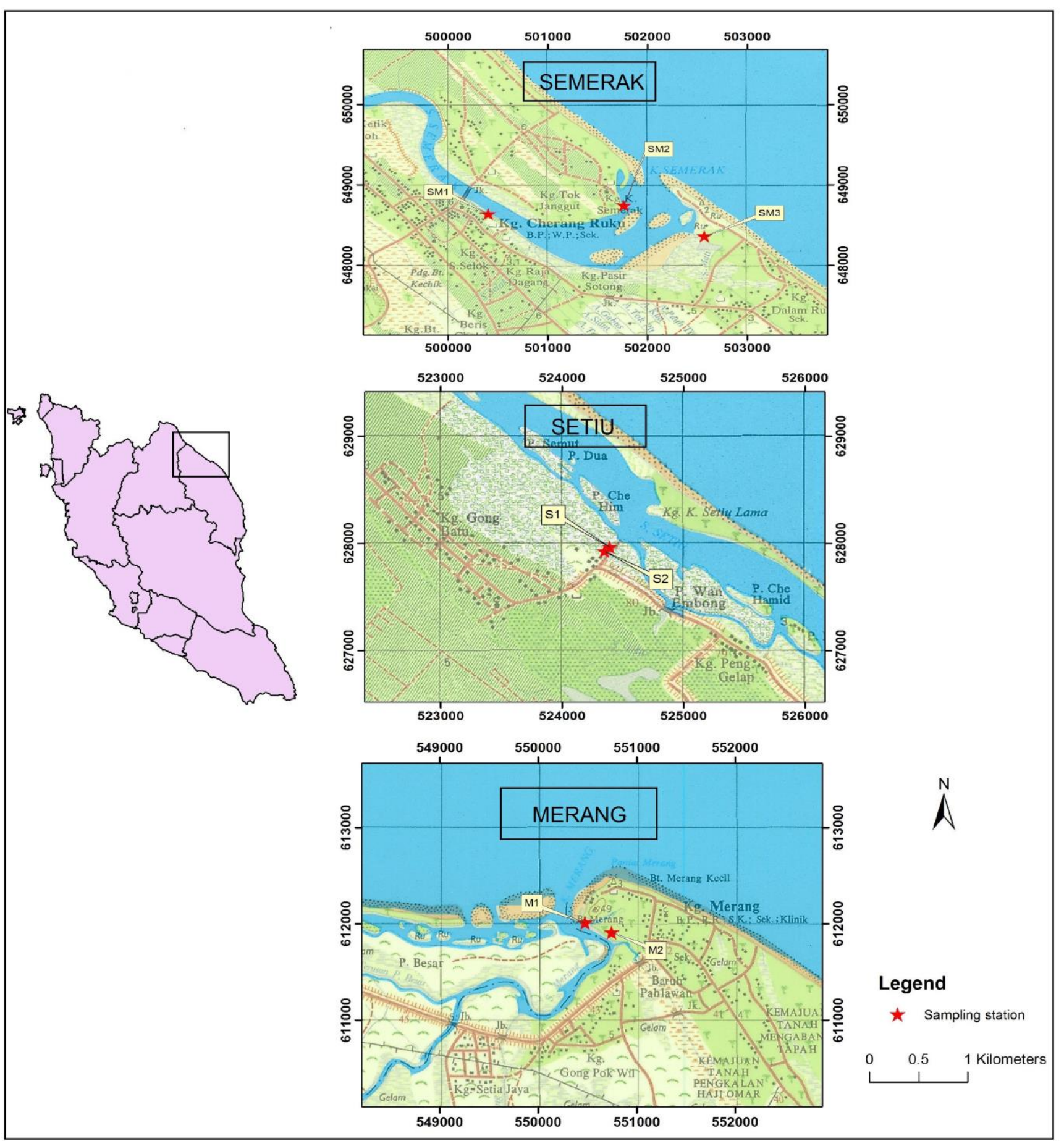

Fig. 1 Locations of sampling stations

\section{EXPERIMENTAL}

\section{Study Area}

Water samples were collected in June 2016 until September 2016 during dry season at three sampling stations in Semerak Lagoon, two sampling stations in Setiu Wetland and two sampling stations at Merang river estuary (Fig. 1). All these station situated at east coast of peninsular Malaysia facing the South China Sea. Semerak lagoon is originated from Semerak River Basin which is semi-enclosed lagoon with a total area $1.7 \mathrm{~km} 2$ with an average depth of $3.12 \mathrm{~m}$ located in Pasir Puteh, Kelantan. This lagoon contain 5,304,000 $\mathrm{m}^{2}$ water during high tide (Shaari et al. 2015). Setiu wetland and Merang estuary situated at Setiu district, Terengganu. Merang River Basin with $39,115,835.46 \mathrm{~m}^{2}$ immensity is the shortest river basin in Setiu district $(8 \mathrm{~km})$ with catchment area $\mathrm{km}^{2}$. Setiu River Basin has catchment area $188 \mathrm{~km}^{2}$ approximately and is $52 \mathrm{~km}$ long and $148,535,660.9 \mathrm{~m}^{2}$ immensity (DID, 2014). Setiu Wetland covers 23,000 ha area and the water column is well mixed and shallow (Suratman et al. 2016).

Table 1. Information of monitoring stations.

\begin{tabular}{cccc}
\hline Station & Latitude & Longitude & Description \\
\hline SM1 & $5^{\circ} 86^{\prime} 50.50 " \mathrm{~N}$ & $102^{\circ} 49^{\prime} 40.00^{\prime \prime} \mathrm{E}$ & Semerak Lagoon \\
SM2 & $5^{\circ} 86^{\prime} 60.32 " \mathrm{~N}$ & $102^{\circ} 50^{\prime} 62.95^{\prime \prime} \mathrm{E}$ & Semerak Lagoon \\
SM3 & $5^{\circ} 86^{\prime} 25.74 " \mathrm{~N}$ & $102^{\circ} 51^{\prime} 35.70 " \mathrm{E}$ & Semerak Lagoon \\
S1 & $5^{\circ} 67^{\prime} 83.80 " \mathrm{~N}$ & $102^{\circ} .71^{\prime} 07.60^{\prime \prime} \mathrm{E}$ & Setiu Wetland \\
S2 & $5^{\circ} 67^{\prime} 80.40 " \mathrm{~N}$ & $102^{\circ} 71^{\prime} 03.70 " \mathrm{E}$ & Setiu Wetland \\
M1 & $5^{\circ} 53^{\prime} 43.40 " \mathrm{~N}$ & $102^{\circ} 94^{\prime} 62.70 " \mathrm{E}$ & Merang Jetty \\
M2 & $5^{\circ} 53^{\prime} 34.30^{\prime \prime} \mathrm{N}$ & $102^{\circ} 94^{\prime} 87.00^{\prime \prime} \mathrm{E}$ & Merang Jetty \\
\hline
\end{tabular}




\section{Sample collection and preparations}

The water quality parameters selected in this study refers to the Marine Water Quality Index (MWQI) (DOE, 2015) as a guideline which include dissolved oxygen (DO), $\mathrm{pH}$, biochemical oxygen demand (BOD), Salinity (SAL), total dissolved solids (TDS), ammonium ( $\left.\mathrm{NH}_{4}-\mathrm{N}\right)$, turbidity (TUR), total suspended solid (TSS) and coliform. Water sampling were conducted during high and low tides and collected from subsurface water into $1 \mathrm{~L}$ high density polyethylene (HDPE) bottles prewashed with dilute hydrochloric acid (10\%) and rinsed three times with water sample. The samples were stored at $4{ }^{\circ} \mathrm{C}$ and were transferred to the laboratory for analysis. Water sampler was used to collect water samples on the spot for detecting physicochemical parameters. In situ measurements such as DO, SAL, TDS, pH, $\mathrm{NH}_{4} \mathrm{~N}$, TUR, and BOD were performed using YSI Multi Parameter Water Quality Sonde, Modern Water BODChek and HACH Turbidity Meter. TSS were analysed in the laboratory using a method by APHA (APHA, 1998). The TSS was calculated using gravimetric method which based on the weight of the filter after samples were filtered $(0.45 \mu \mathrm{m}$ filters, Milipore) and dried at room temperature within 24 hours. Coliform was calculated using $1 \mathrm{ml}$ of fresh water sample which was pipetted on $3 \mathrm{M}^{\mathrm{TM}}$ petrifilm plates. The samples were incubated for 18 hour at $37^{\circ} \mathrm{C}$ (APHA, 1998).

\section{Statistical analysis}

Statistical analysis was performed using XLSTAT 2014 software. The box plot is a visualizing data which represent the descriptive statistics of the data set. The famous 'stem and leaf diagram' in box plot are representing data semi graphically (Tukey, 1990). Besides, the ANOVA Single Factor was used to reveal the significant value of each water quality parameter at the $95 \%$ confidence level $(a=0.05)$.

\section{Principal component analysis}

Purposely, Principal Component Analysis (PCA) was used to reduce the number of variables and to detect structure in the relationship among the variables. PCA also signifies the most significant parameters by exhibiting the source of variation that has been depicted from the whole data set. In this approach, the less significant variables were omitted from the whole data set with a very minimum loss of its original information in the analysis. Principally, the varimax rotations applied to PCs with eigenvalues more than one are considered significant in obtaining new groups of factors known as varimax factors (VFs) (Dominick et al. 2012; Vega et al. 2011; Juahir et al. 2004).

\section{RESULTS AND DISCUSSION}

Figure 2 shows the distribution of marine water quality parameters. The ranges of parameters in all stations were recorded. Based on Table 2, ANOVA shows significant difference $(\mathrm{p}<0.05)$ for all parameters between Semerak, Setiu Wetland and Merang. This can be strengthened further by box and whiskers plot in Fig. 2 .

Table 2 Anova Single Factor.

\begin{tabular}{lccccc}
\hline Parameter & $\boldsymbol{F}$ & $\boldsymbol{P}$-value & $\boldsymbol{F}$ crit & Average & $\begin{array}{c}\text { Std. } \\
\text { Deviation }\end{array}$ \\
\hline $\mathrm{DO}$ & 26.18 & 0.00 & 3.18 & 3.09 & 0.88 \\
$\mathrm{BOD}$ & 17.61 & 0.00 & 3.15 & 1.36 & 0.44 \\
$\mathrm{pH}$ & 21.53 & 0.00 & 3.16 & 7.16 & 0.50 \\
$\mathrm{NH}_{4}-\mathrm{N}$ & 34.87 & 0.00 & 3.18 & 53.53 & 22.32 \\
$\mathrm{SAL}$ & 26.72 & 0.00 & 3.16 & 16.68 & 4.81 \\
$\mathrm{TUR}$ & 27.88 & 0.00 & 3.28 & 15.13 & 6.94 \\
$\mathrm{TSS}$ & 11.53 & 0.00 & 3.32 & 40.03 & 22.57 \\
TDS & 31.85 & 0.00 & 3.16 & 17994.35 & 5177.66 \\
Coliform & 11.39 & 0.00 & 3.32 & 182.90 & 64.96 \\
\hline
\end{tabular}

*One-way Anova Single Factor shows significant different between each marine water quality parameters $(p>0.05)$.
The highest DO concentration average was recorded at Semerak while Setiu has the lowest concentration average of DO. Decrease of DO content caused by the presence of pollutants such as heavy metals in that area (Fashchuk. 2011). Four out nine parameters (BOD, TUR, TSS and Coliform) show Setiu Wetland gives the highest concentration average of parameters than Semerak and Merang. Salinity and $\mathrm{pH}$ for Merang show the highest value because of the M1 and M2 located in river mouth of the Merang River. Futhermore, $\mathrm{pH}, \mathrm{NH}_{4}-\mathrm{N}$ and TDS also give the highest concentration average for Merang, due to the same condition. Semerak Lagoon. Based on the findings, Setiu Wetland is more polluted than Merang and Semerak according to Class E of the Marine Water Quality Standard and Criteria (DOE, 2015). Recently, several studies in Setiu Wetland has been reported. Agricultural (oil palm plantation) and aquaculture activities (cage culture, pen culture, oyster farming and pond culture) are the core dubious factors which are changing the fresh water inputs to the wetland (Koh et al. 2015; Suratman et al. 2014; Kamaruzzaman et al. 2009).

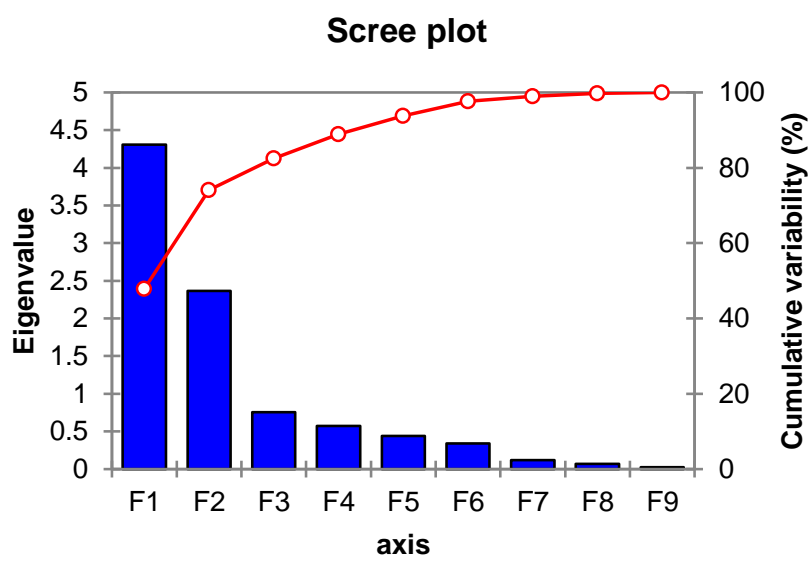

Fig. 3 Scree plot of eigenvalues.

Scree Plot in Figure 3 shows eigenvalues from PCA. Eigenvalues of the correlation matrix which represent a partitioning of the total variation accounted for each principal component. This is a plot of the eigenvalues associated with each of the factors extracted, against each factor. At the point that the plot begins to level off, the additional factors explain less variance than a single variable. There are two factors which eigenvalues more than 1 (4.3077 and 2.364). These two factors indicate two rotations in PCA. That means, nine marine water quality parameters were reduced to two factors.

Table 3 presents factor loadings after varimax rotation (according to eigenvalues). PCA of the entire data set (Table 3) involved two principal components with eigenvalues greater than one explaining about $74.13 \%$ of the total variance in the water-quality data set. VF1 shows $47.86 \%$ of total variance for $\mathrm{pH}, \mathrm{NH}_{4}-\mathrm{N}$, SAL, and TDS. This varimax factor represents the saltwater intrusion into river mouth of mangrove area due to high salinity in estuary condition (Hairoma et al. 2016). The presence of $\mathrm{NH}_{4}-\mathrm{N}$ was caused by anthropogenic activities and manure from livestock. As with salinity, the limited strength of the higher low tide gave higher $\mathrm{NH}_{4}-\mathrm{N}$ concentrations (Wong et al. 1995). Biplot chart in Fig. 4 represents the water quality parameters simultaneously in the new space. Which shows VF1 linked with M1 and M2 station. VF2 presents $26.27 \%$ total variance of strong positive loadings of BOD, TUR and Coliform and strong negative loading of DO. This VF represents the anthropogenic activities that is linked to agriculture and aquaculture (Suratman et al. 2014). High BOD concentration influences of bad water quality which is caused by aquaculture activities. the strong significant correlation caused by the high levels of dissolved organic matter that will unavoidably deplete large amounts of oxygen hence reducing the levels of DO required in brackish water at the mangrove estuary (Vega et al. 2011). Besides, this result was reliable with the previous study which said the high levels of organic matter from aquaculture discharged originating from conceiving from faeces, organic fertilizer and feedstuff (Hairoma et al. 2016; Koh et al. 2015; Suratman et al. 2014; Alongi et al. 2009; Wong et al. 1995;). 


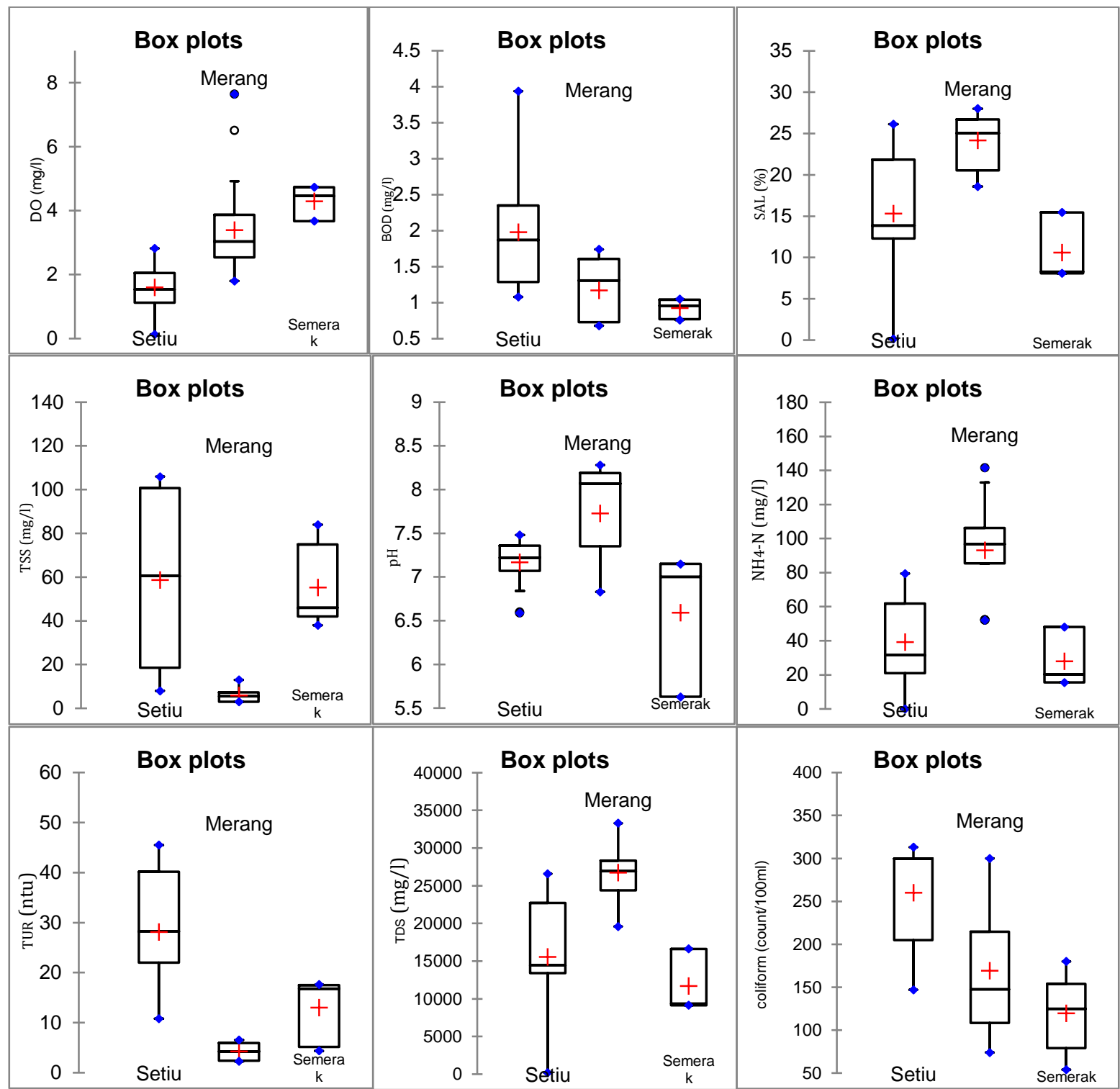

Fig. 2 Box plot of water quality parameters measured.

Table 3 Factor Loading after varimax rotation

\begin{tabular}{lcc}
\hline & VF1 & VF2 \\
\hline $\mathrm{DO}$ & 0.1895 & $\mathbf{- 0 . 8 0 1 5}$ \\
$\mathrm{BOD}$ & 0.0395 & $\mathbf{0 . 7 9 6 0}$ \\
$\mathrm{pH}$ & $\mathbf{0 . 7 3 4 4}$ & -0.2339 \\
$\mathrm{NH}_{4} \mathrm{~N}$ & $\mathbf{0 . 9 1 4 6}$ & -0.3060 \\
$\mathrm{SAL}$ & $\mathbf{0 . 9 5 6 6}$ & -0.0833 \\
$\mathrm{TUR}$ & -0.5369 & $\mathbf{0 . 7 2 8 4}$ \\
TDS & $\mathbf{0 . 9 0 6 2}$ & 0.0154 \\
TSS & -0.6088 & -0.3982 \\
Coliform & -0.0697 & $\mathbf{0 . 8 5 8 9}$ \\
\hline Eigenvalue & 4.3077 & 2.3640 \\
Variability (\%) & 47.8635 & 26.2671 \\
Cumulative \% & 47.8635 & 74.1306 \\
\hline
\end{tabular}

The presence of coliform which is caused by faecal waste also suspected to be originated from the same point source pollution (Mohd et al. 2011). Based on Fig. 3, S1 and S2 are included in VF2. Interestingly, SM1, SM2 and SM3 are not in any VF because of the significant differences in water quality compared to the other stations. Thus, Semerak Lagoon is considered as having good quality of water compared to Setiu Wetland and Merang estuary.

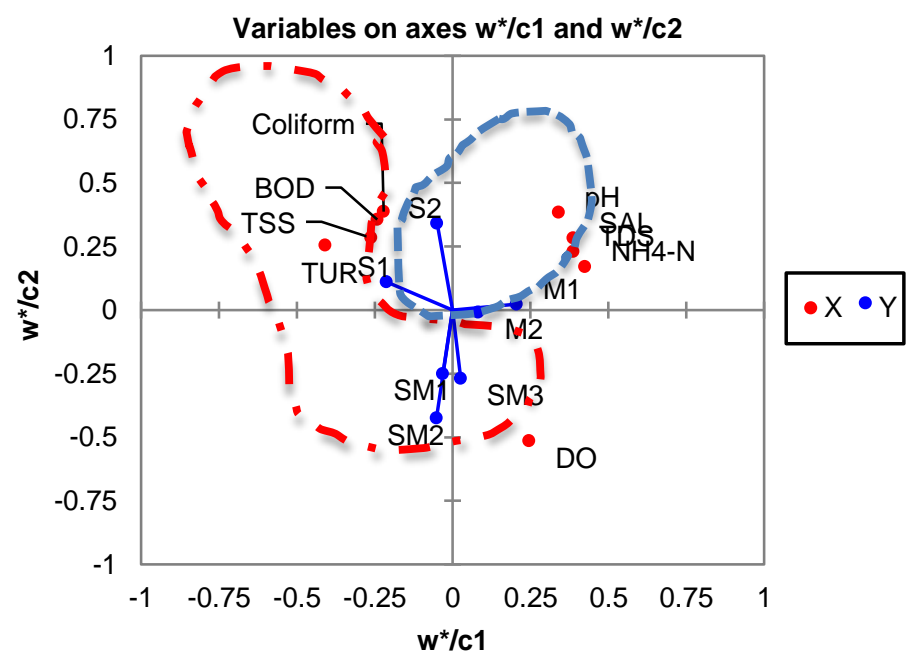

Fig. 3 Biplot chart after varimax rotation.

* Biplot chart in figure 3 shows VF2 linked with S1, S2, SM1, SM2 and SM3 station. 


\section{CONCLUSION}

This is the preliminary study reassessment of marine water quality status of mangrove estuary at selected area in the east coast of peninsular Malaysia. This study consist of three mangrove estuary areas (Semerak, Setiu and Merang) which were chosen based on lack of water quality status studies in mangrove ecosystems which act as a baseline study in marine water quality at estuary for the future research. From the finding of PCA, the pollution apportionment from these three areas which affect marine water quality status include saltwater intrusion and anthropogenic activities. The outcomes show that Semerak lagoon has good marine water quality status compared to Setiu Wetland and Merang estuary. Hence, long term monitoring for these areas need to be undertaken to ensure the water quality for mangrove estuary will not degrade and that the health of mangrove ecosystem is sustainably conserve. Future study should focus on developing a workable water quality modelling as exquisite tool to simulate marine water quality and forecast future consequences which will help mangrove biodiversity conservation.

\section{ACKNOWLEDGEMENT}

The authors would like to thanks Jawatankuasa Teknikal Mengenai Pendidikan dan Pembangunan Program Penanaman Bakau dan Spesis yang Sesuai di Persisiran Pantai Negara (JTRD) for supporting the present study (Grant No. UNISZA/FRIM/2016/1).

\section{REFERENCES}

Alongi, D. M., McKinnon, A. D., Brinkman, R., Trott, L. A., Undu, M. C., Muawanah and Rachmansyah. (2009). The fate of organic matter derived from small-scale fish cage aquaculture in coastal waters of Sulawesi and Sumatra, Indonesia. Aquaculture. 295(1/2): p. 60-75.

APHA (1998). Standard Methods for the Examination of Waste and Wastewater American Public Health Association, American Water Works Association and Water Environmental Federation, Washington DC.

Department of Environment, Malaysia (2015). Malaysia Environmental Quality Report 2014. Retrived from http://enviro.doe.gov.my/

Department of Irrigation and Drainage, Malaysia (2015). Laporan Banjir Tahunan 2014 Terengganu. Retrieved from http://jpsweb.terengganu.gov.my/ index.php/ en/laporan-banjir

Dominick, D., Juahir, H., Latif, M. T., Zain, S. M., \& Aris, A. Z. (2012). Spatial assessment of air quality patterns in Malaysia using multivariate analysis. Atmospheric Environment. 60: p. 172-181.

Duke, N. C., Meynecke, J. O., Dittmann, S., Ellison, A. M., Anger, K., Berger, U., Cannicci, S., Diele, K., Ewel, K. C., Field, C. D., Koedam, N., Lee, S. Y., Marchand, C., Nordhaus, I., Dahdouh-Guebas, F. (2007). A world without mangroves? Science. 317(5834): p. 41-42.

Fashchuk, D. Y. (2011). Geographic and ecological information model of marine basin, In: Marine Ecological Geography. Environmental Science and Engineering. Berlin, Heidelberg: Springer.

Hairoma, N., Gasim, M. B., Azid, A., Muhamad, H., Sulaiman, N. H., Khairuddin, Z., Mustafa,. A. D., Azaman, F., Amran, M. A. (2016). Saltwater intrusion analysis in East Coast of Terengganu using multivariate analysis. Malaysian Journal of Analytical Sciences. 20(5): p. 1225-1232.

Hauff, R. D., Ewel, K. C. and Jack, J. (2006). Tracking human disturbance in mangroves: estimating harvest rates on a Micronesian Island. Wetlands Ecology and Management. 14(2): p. 95-105.

Holguin, G., Vazquez, P. and Bashan, Y. (2001). The role of sediment microorganisms in the productivity, conservation, and rehabilitation of mangrove ecosystems: an overview. Biology and Fertility of Soils. 33(4): p. 265-278.

Ismail, W. R. and Ibrahim, M. N. (2015). An assessment of sediment and nitrogen input into the upper Merbok Estuary, Kedah, Malaysia. Water Quality, Exposure and Health. 7(1): p. 79-88.

Juahir, H., Zain, S. M., Toriman, M. E., Mokhtar, M., Man, H. S. (2004). Application of artificial neural network models for predicting water quality index. Jurnal Kejuruteraan Awam. 16(2): p. 42-55.

Kamaruzzaman, B. Y., Ong, M. C., Noor Azhar, M. S., Shahbudin, S., Jalal, K. C. A. (2009). Accumulation of lead and copper in Rhizophora apiculata from Setiu mangrove forest, Terengganu, Malaysia. Journal of Environmental Biology. 30(5). 821-824

Koh, K., Suratman, S., Mohd Tahir, N. (2015). Dissolved and suspended particulate metals in Setiu River Basin, Terengganu, Malaysia. Sains Malaysiana. 44(7): p. 957-964.

Kumar, S. and Murty, M. (2011). Water pollution in India: An economic appraisal. Indian Infrastructure Report.

Mohd, I., Mansor, M. A., Awaluddin, M. R. A., Nasir, M.F.M., Samsudin, M.S., Juahir H. and Ramli, N. (2011). Pattern recognition of Kedah river water quality data by implementation of principal component analysis. World Applied Sciences Journal. 14. p. 66-72.

Mumby, P. J. (2004). Mangroves enhance the biomass of coral reef fish communities in the Caribbean. Nature. 427(6974): p. 533-536.

Praveena, S. M. and Aris, A. Z. (2013). A baseline study of tropical coastal water quality in Port Dickson, Strait of Malacca, Malaysia. Marine Pollution Bulletin. 67(1): p. 196-199.

Sandilyan, S. and Kathiresan, K. (2014). Decline of mangroves-A threat of heavy metal poisoning in Asia. Ocean \& Coastal Management. 102: p. 161168.

Satheeshkumar, P. and Khan, A. B. (2012). Identification of mangrove water quality by multivariate statistical analysis methods in Pondicherry Coast, India. Environmental Monitoring and Assessment. 184(6): p. 3761-3774.

Shaari, H., Mohd, M. S., Abdullah, N. A., Bidai, J. (2015). Heavy metals monitoring in Psammotaea elongata from Semerak Lagoon, Kelantan, Malaysia. Oriental Journal of Chemistry. 31(2): p. 993-999.

Suratman, S. and Hussein, A. N. A. R. and Latif, M.T. and Weston, K. (2014). Reassessment of physico-chemical water quality in Setiu Wetland, Malaysia. Sains Malaysiana. 43(8): p. 1127-1131.

Suratman. S, Hussein, A. N. A. R, Mohd Tahir, N., Latif, M. T., Mostapa, R., Weston, K. (2016). Seasonal and spatial variability of selected surface water quality parameters in Setiu Wetland, Terengganu, Malaysia. Sains Malaysiana. 45(4): p. 551-558.

Tukey, J. W. (1990). Data-based graphics: Visual display in the decades to come. Statistical Science. 5(3): p. 327-339.

Vega, M., Pardo, R., Barrado, E., Deban, L. (2011). Assessment of seasonal and polluting effects on the quality of river water by exploratory data analysis. Water Research. 32(12): p. 3581-3592.

Wong, Y. S., Lan, C. Y., Chen, G. Z., Li, S. H., Chen, X. R., Liu, P. Z., Tam, N F. Y. (1995). Effect of wastewater discharge on nutrient contamination of mangrove soils and plants. Hydrobiologia. 295(1-3): p. 243-254. 